\title{
MODEL ORGANISASI DINAS PENDIDIKAN DALAM PENGELOLAAN PENDIDIKAN ANAKSECARA EFEKTIF: STUDI KASUSDAERAH PASCAKONFLIK KOTA AMBON
}

\author{
Nur Hasanah \\ Fakultas'TarbiyahdanIlmuKeguruan (FTIK) \\ InstitutAgamaIslam Negeri (IAIN) Ambon
}

\begin{abstract}
The future development supported education is the education which be able to advance the children's ability. Consequently, the children are capable of facing and solving the problems in their life. That education concept is significant when the children enter the real obstacles in a society or work life. Furthermore, the children have to administer what they already learn at school to solve the problem not only in their daily life but also in the society. An educational organization model crucially ascertains the successful process of children education in the rural area. The goal of this article is to learn more about the effective educational organization model applied in a conflict area, specifically in Ambon. Moreover, it needs an innovative model to enhance the education institution in Ambon. The education institution model in Ambon employs a bureaucracy model, the top-down bierarchy system to control the activity in every education institution there.
\end{abstract}

Keywords:

Organization model, Education, Conflict

\section{PENDAHULUAN}

Konflik yang benuansa SARA di daerah tertentu yang ada di Indonesia, salah satunya adalah Ambon yang terletak di provinsi Maluku adalah akibat dari lemahnya pemahaman dan pemaknaan tentang konsep kearifan budaya. Konflik akan muncul apabila tidak ada distribusi nilai yang adil kepada masyarakat. Terdapat perbedaan ras pada masyarakat menjadi penanda awal yang secara budaya sudah dilabelkan hambatan-hambatannya, Dengan kata lain dinamika dan perkembangan masyarakat Indonesia kedepan sangat dipengaruhi oleh hubungan-hubungan antar etnis.

Disadari bahwa untuk membangun suatu lembaga pendidikan di daerah pascakonflik adalah cukup sulit. Mengapa? karena untuk mengembalikan keharmonisan seperti semula atau prakonflik butuh proses lama. Kondisi psikologis anak-anak yang berada di daerah pascakonflik juga tentu berbeda dengan kondisi pada anak-anak di daerah yang lebih kondusif pada umumnya. Anak-anak ini mengalami tekanan berat dan rasa trauma yang dapat mengganggu proses perkembangan mereka. Praktisi pendidikan Arief Rahman menilai, anak-anak tersebut lebih membutuhkan pendidikan informal untuk mengembalikan kondisi psikologisnya:

Anak-anak yang mengalami trauma akibat konflik, belum mampu menerima materi pendidikan formal yang kaku. Mereka lebih membutuhkan pendidikan informal yang lebih banyak berisi kegiatan pembentukan karakter. ${ }^{1}$

Pendidikan menjadi hal yang paling sering menjadi sorotan, karena lewat pendidikanlah sesuatu perubahan dimulai. Penciptaan generasi muda yang memiliki kemampuan ilmu pengetahuan yang dengan ilmu pengetahuan itu dapat melakukan pembangunan di segala bidang merupakan alasan umum mengapa pendidikan menjadi begiu penting. Berdasarkan permasalahan di atas, untuk membangun pendidikan secara efektif di daerah pascakonflik pemerintah daerah

\footnotetext{
${ }^{1}$ A. Rahman, 2009. "Pengembangan Mobil Pintar untuk Daerah Tertinggal, Pasca Konflik, dan Rawan Bencana".http://edukasi.kompas.com/read/2009/08/06/14542844/ Arief. Anak di Daerah Konflik Butuh Pendidikan Informal. Diakses 15 Oktober 2014. Hal 6
} 
khususnya di dinas pendidikan harus mempunyai inisiatif untuk merubah model struktur organisasi yang mampu mewujudkan pendidikan secara efektif.

\section{MODEL ORGANISASI}

Model dimaknai sebagai suatu objek atau konsep yang digunakan untuk mempresentasikan sesuatu hal. ${ }^{2}$ Mills menyatakan bahwa model adalah bentuk representatif akurat sebagai proses aktual yang memungkinkan seseorang atau sekelompok orang mencoba bertindak berdasarkan model itu. Model merupakan interpretasi terhadap hasil observasi dan pengukuran yang diperoleh dari beberapa sistem. Ada beberapa macam model organisasi yang bisa diterapkan di bidang pendidikan, diantaranya: ${ }^{3}$

\section{Model Birokrasi}

Tipe model biroksasi semula dikembangkan oleh Max Weber. Model birokasi Weber memiliki enam pokok dasar, yaitu

a. Dalam organisasi ada pembagian tugas dan spesialisasi. Setiap individu dalam organisasi mempunyai wewenang yang diatur oleh peraturan, kebijakan, dan ketetapan hukum

b. Hubungan dalam organisasi bersifat inperonal

c. Dalam organisasi ada hirarki wewenang, di mana yang rendah patuh kepada perintah yang lebih tinggi

d. Administrasi selalu dilaksanakan dengan dokumen tertulis

e. Orientasi pengembangan pegawai adalah pengembangan karir yang berarti keahlian merupakan kriteria utama diterima atau ditolaknya seseorang sebagai anggota organisasi dan berlaku pula untuk mempromosikannya

f. Untuk mendapatkan efisiensi maksimal, setiap tindakan yang diambil harus selalu dikaitkan dengan besarnya sumbangan terhadap pencapaian tujuan organisasi.

Weber selanjutnya membandingkan organisasi kedalam dua tipe, yaitu: 1) tipe organisasi kharismatik, organisasi yang dipimpin oleh seorang pemimpin yang memiliki pengaruh pribadi yang sangat besar bagi anggotanya, dan 2) organisasi tradisional, organisasi yang pemimpinnya diangkat berdasarkan warisan. Dalam pengambilan keputusan, Weber berpendapat bahwa keputusan yang diambil harus menghindari penggunaan emosi dan perasaan suka atau tidak suka. Birokrasi adalah usaha untuk menghilangkan tradisi organisasi yang membuat keputusan secara emosional atau berdasarkan ikatan kekeluargaan yang dapat menyebabkan organisasi tersebut tidak efisien dan tidak sehat. ${ }^{4}$

\section{Model Egaliter.}

Konsep Egaliter adalahkesamaan dalam otoritas dan kesamaan hak bagi setiap orang dalam kelompok. Kontribusi setiap orang bagi kelompok memiliki makna yang sama pentingnya. Setiap anggota boleh masuk dan keluar kapanpun dia mau. Dilihat dari pemenuhan kebutuhan dasar manusia, model mesin bisa memberikan kebutuhan dasar fisik dan keamanaan sedangkan model egaliter bisa memberikan kepuasan pada kebutuhan sosial, ego dan aktualisasi diri.

Model egaliter didasarkan pada kerjasama antar anggota kelompok dengan cara sukarela. Kerjasama ini dianggap sebagai suatu cara untuk mengatasi keterbatasan setiap anggota yang terlibat di dalamnya baik kekurangan jasmaniah, lingkungan, psikologis, dan sosial. Jika suatu kelompok ingin eksis maka persaingan antar anggota kelompok harus diminimalkan. Margaret Mead yang melakukan penelitian di masyarakat primitif mengelompokkannya menjadi: kompetitif, kooperatif,dan individualistis. Karena kerjasama merupakan bagian penting dari keberlangsungan

\footnotetext{
${ }^{2}$ Trianto, Model-model Pembelajaran Inivatif Berorientasi Konstruktivistik(Jakarta: Kencana Prenada Media Group, 2009). Hal 21

${ }^{3}$ A. Suprijono, 2009. CooperativeLearning (Surabaya: Pustaka Pelajar, 2009). Hal 45.

${ }^{4}$ Usman Husaini, Manajemen Teori, Praktik, dan Riset Pendidikan. Edisi 4. (Yogyakarta: Bumi Aksara, 2013). Hal 41.
} 
hubungan, dia menemukan tiga metode dasar di mana kompetisi dikurangi, sementara kerjasama ditingkatkan tidak perduli dasar apa yang dipakai di suatu masyarakat.

Karakteristik model federasi hampir sama dengan model egaliter hanya ada tambahan yang baru di sini berupa kegiatan-kegiatan yang sifatnya otonomi dan pemenuhan diri dalam kelompoknya masing-masing. Karakteristik berikutnya dalam kegiatan sehari-hari tidak adanya pemaksaan dalam hubungan atasan bawahan. Masing-masing kegiatan diharapkan berjalan seirama dengan yang lain tanpa sistem pengendalian yang rumit. Tujuan di setiap unitnya harus secara alami menyesuaikan dengan tujuan besarnya perusahaan. Otonomi bermakna bahwa masing-masing unit kegiatan mampu melakukan atau menjalankan urusannya sendiri melalui cara yang paling efisien untuk kebaikan perusahaan secara menyeluruh, dan memang setiap unit mempunyai tanggungjawab dan otoritas untuk melakukan yang demikian, namun keberhasilannya tergantung pada kekayaan federasi secara keseluruhan. Konsep otonomi kelompok dalam sebuah perusahaan dapat digambarkan sebagai berikut:

a. Peran manajemen. melaksanakan fungsi kordinasi seperti menyediakan pedoman kebijakan umum, pelayanan khusus tertentu seperti data prosessing, penelitian dan pengembangan untuk setiap unit.

b. Profesionalisasi. Meningkatnya devisi kerja yang bermacam-macam dan spesialisasi fungsifungsi kerja tidak hanya disebabkan oleh industrialisasi tapi memang muncul karena kebutuhan

c. Keuntungan absolut. Adam Smith mengatakan meningkatnya devisi dalam pekerjaan dikarenakan faktor ingin berubah yang merupakan sifat alami manusia.

d. Keuntungan komparasi. proses produksi barang disuatu negara dibandingkan dengan negara lain karena perbedaan sumber alam dan tenaga sehingga menyebabkan harga satu barang di suatu negara bisa lebih murah atau lebih mahal dari negara lain.

\section{Organisasi Kolegial}

Karakteristik yang paling menonjol dari organisasi kolegial (organisasi yang menghasilkan pengetahuan) adalah bahwa spesialis yang posisinya bawahan justru yang menggerakkan dan mengarahkan kegiatannya atasan (administrator puncak). Sementara organisasinya sendiri terdiri dari sejawat sejawat yang profesional maka organisasi ini disebut organisasi kolegial.

Organisasi kolegial terdiri dari dua komponen dasar. Pertama, kelompok independen, profesionalis yang bisa mendapati dirinya dalam organisasi dimana mereka tetap ada, meneliti, dan secara aktif melakukan pencarian pengetahuan. Komponen kedua adalah koponen yang melakukan fungsi kerumahtanggaan dimana mereka ini menjaga agar organisasi tetap berjalan dan juga dapat melayani komponen pertama agar tetap menghasilkan pengetahuan. Dua komponen ini berbeda dan terpisah. Kerumahtanggaan ditata dengan menggunakan organisasi model mesin, sedang komponen spesialis ditata dalam organisasi yang berbeda.

Untuk mengkordinasikan kegiatan kelompok spesialis ini tidak menggunakaan hubungan atasan bawahan tetapi menggunakan komunitas kelembagaan sebagai alat kordinasinya hal ini dilakukan untuk menghindari keharusan bagi pimpinan tinggi untuk membimbing kegiatan pada anggotanya.

\section{Model Desentralisasi}

Tiga makna desentralisasi:a) Literatur lama menekankan pemisahan fasiliatas berdasar geografis;b) Literatur terkini menggambarkan dorongan pembuatan keputusan oleh tingkat yang paling bawah dalam organisasi;c) Menggabungkan dua hal itu dalam suatu filosofi atau sikap bahwa tiap orang bisa berfikir untuk dirinya sendiri, pemenuhan diri, dan mampu belajar melalui pengalaman praktis. Karakteristik model desentralisasi adalah bahwa setiap kegiatan unit dalam organisasi adalah otonom. 


\section{Model Administrasi umum}

Orang Amerika meyakini untuk menghindari tekanan otonomi, agama, politik, gengsi atau dominasi sosial atau tekanan individual lainnya, maka seorang individu harus mampu mempengaruhi ekonomi agama politik tersebut yang berpengaruh pada dirinya, demikian juga harus mampu mempengaruhi lembaga yang didirikan secara politik.

Namun demikian terdapat suatu model organisasi cukup tua yang bertujuan memecahkan permasalahan penetapan tujuan dan kebijakan birokrasi untuk menuju kepuasan yang diinginkan konsumen. Model tersebut yaitu model organisasi pemerintahan atau model perusahaan. Model ini konsisten pada komite/dewan yang dipilih atau ditetapkan organisasi dan secara langsung berusaha untuk mencapai tujuan khusus oragnisasi.Contoh: perusahaan di Amerika pemiliknya memilih anggota-anggota dewan direksi, dewan sebagai pemegang kewenangan organisasi

Dalam model Administrasi publik asumsinya adalah dewan pemerintah akan menentukan kebijakan dan birokrasi yang akan mempertanggung jawabkan kebijakan administrasi. ${ }^{5}$

\section{PENDIDIKAN}

Pendidikan merupakan proses sistematis untuk meningkatkan martabat manusia secara holistik. Dengan demikian, pendidikan seyogyanya menjadi wahana strategis bagi upaya mengembangkan segenap potensi individu, sehingga cita-cita membangun manusia Indonesia seutuhnya dapat tercapai. ${ }^{6}$

Terdapat beberapa pandangan mengenai pengertian pendidikan, seperti yang lazim digunakan dalam praktik pendidikan. Dalam hubungan ini dijumpai berbagai rumusan yang berbeda-beda. Ahmad D. Marimba, misalnya mengatakan bahwa pendidikan adalah bimbingan atau pimpinan secara sadar oleh si pendidik terhadap perkembangan jasmani dan rohani si terdidik menuju terbentuknya kepribadian yang utama. Berdasarkan rumusannya ini, Marimba menyebutkan ada lima unsur utama pendidikan, yaitu 1). Usaha (kegiatan) yang bersifat bimbingan, pimpinan atau pertolongan yang dilakukan secara sadar. 2). Ada pendidik, pembimbing atau penolong. 3). Ada yang dididik, atau si terdidik. 4). Adanya dasar dan tujuan dalam bimbingan tersebut. 5). Dalam usaha itu tentu ada alat-alat yang dipergunakan. ${ }^{7}$

Menurut Ahmad Tafsir definisi tersebut dinilai sebagai definisi yang belum mencakup semua yang dikenal sebagai pendidikan. Definisi tersebut cukup memadai bila pendidikan dibatasi hanya pada pengaruh seseorang kepada oranglain, dengan sengaja (sadar). Pendidikan oleh diri sendiri dan oleh lingkungan, nampak belum mencakup ke dalam batasan pendidikan dalam pandangan A.D. Marimba tersebut. Namun demikian Ahmad Tafsir lebih lanjut mengatakan bahwa pengertian mana yang akan anda ambil, boleh saja, terserah kepada anda. ${ }^{8}$

Formulasi pendidikan selanjutnya seperti yang diajukan oleh tokoh pendidikan nasional, Ki Hajar Dewantara. Pendidikan adalah usaha yang dilakukan dengan penuh keinsyafan yang ditujukan untuk keselamatan dan kebahagiaan manusia. Pendidikan tidak hanya bersifat pelaku pembangunan tetapi merupakan perjuangan. Pendidikan berarti memelihara hidup tumbuh kearah kemajuan.

Pendidikan adalah usaha kebudayaan, berazaz peradaban, yakni memajukan hidup agar mempertinggi derajat kemanusiaan. ${ }^{9}$ Rumusan pendidikan ini nampak memberikan kesan dinamis,

\footnotetext{
${ }^{5}$ Sonhadji, Bahan-bahan Perkuliahan Teori dan Model dalam Bidang Studi. (Malang: Universitas Negeri Malang Program Pascasarjana, 2013). Hal 51-149

${ }^{6}$ Depdiknas, 2005. Rencana Strategis Departemen Pendidikan Nasional Tahun 2005 - 2009(Jakarta: Departemen Pendidikan Nasional).

${ }^{7}$ Ahmad D. Marimba,Pengantar Filsafat Pendidikan Islam(Bandung: Al- Ma'arif, 1962). Hal 19

${ }^{8}$ Ahmad Tafsir, Ilmu Pendidikan dalam Perspektifj'slam, Bandung: Remaja Rosdakarya. cet. IV. Hal 25

${ }^{9}$ Ki HajarDewantara, Bagian Pertama Pendidikan(Yogyakarta: Majelis Luhur Persatuan Taman Siswa, 1962). Hal 166.
} 
modern dan progressif. Pendidikan tidak boleh hanya memberikan bekal untuk membangun, tetapi seberapa jauh didikan yang diberikan itu dapat berguna untuk menunjang kemajuan suatu bangsa.

Pengertian pendidikan yang agak lebih terperinci lagi cakupannya dikemukakan oleh Soegarda Poerbacaraka. Menurutnya, dalam arti umum pendidikan mencakup segala usaha dan perbuatan dari generasi tua untuk mengalihkan pengalamannya, pengetahuannya, kecakapannya, sera keteranpilannya kepada generasi muda untuk melakukan fungsi hidupnya dalam pergaulan bersama sebaik-baiknya. Lebih lanjut, ia menambahkan bahwa corak pendidikan itu erat hubungannya dengan corak penghidupan. Karenanya jika corak penghidupan itu berubah, maka corak pendidikannya akan berubah pula, agar si anak siap untuk memasuki lapangan pendidikan itu. ${ }^{10}$ Definisi yang terakhir ini sejalan dengan definisi K.H. Dewantara sebelumnya. Dan ketiga rumusan pendidikan di atas jika dipadukan akan terlihat bahwa pendidikan merupakan kegiatan yang dilakukan dengan sengaja, seksama,' terencana, dan bertujuan yang dilaksanakan oleh orang dewasa dalam arti memiliki bekal ilmu pengetahuan dan ketrampilan menyampaikannya kepada anak didik secara bertahap. Apa yang diberikan kepada anak didik itu sedapat mungkin dapat menolong tugas dan perannya di masyarakat, dimana kelak mereka hidup.

Pendidikan merupakan suatu proses yang kontinyu. Ia merupakan pengulangan yang perlahan tetapi pasti dan terus-menerus sehingga sampai pada bentuk yang diinginkan. Dari pernyataan diatas, dapat ditarik kesimpulan bahwa pendidikan adalah usaha sadar terencana untuk mewujudkan suasana belajar dan proses pembelajaran atau pelatihan agar peserta didik secara aktif dapat mengembangkan potensi dirinya supaya memiliki kekuatan spiritual keagamaan, emosional, pengendalian diri, kepribadian, kecerdasan, akhlak mulia, serta ketrampilan yang diperlukan dirinya dan masyarakat.

\section{KONFLIK}

Konflik dapat didefinisikan sebagai segala macam interaksi pertentangan atau antagonistic antara dua atau lebih pihak. Konflik organisasi adalah ketidaksesuaian antara dua atau lebih antara anggota-anggota atau kelompok-kelompok organisasi yang timbul karena adanya kenyataan bahwa mereka harus membagi sumber daya yang terbatas atau kegiatan-kegitan kerja atau karena kenyataan bahwa mereka mempunyai perbedaan status, tujuan, nilai atau persepsi ${ }^{11}$. Selain definisi konflik di atas, ada beberapa definisi yang dikemukakan oleh para tokoh, sebagai berikut:

a. Menurut Nardjana, Konflik adalah akibat situasi di mana keinginan atau kehendak yang berbeda atau berlawanan antara satu dengan yang lain, sehingga salah satu atau keduanya saling terganggu.

b. Menurut Killman dan Thomas, konflik merupakan kondisi terjadinya ketidakcocokan antar nilai atau tujuan-tujuan yang ingin dicapai, baik yang ada dalam diri individu maupun dalam hubungannya dengan orang lain.

c. Wood, Walace, Zeffane, Schermerhorn, Hunt, dan Osborn mendefiniskan konflik (dalam ruang lingkup organisasi) adalah: Conflict is a situation which two or more people disagree over issues of organisational substance and/or experience some emotional antagonism with one another, yang kurang lebih memiliki arti bahwa konflik adalah suatu situasi di mana dua atau banyak orang saling tidak setuju terhadap suatu permasalahan yang menyangkut kepentingan organisasi dan atau dengan timbulnya perasaan permusuhan satu dengan yang lainnya.

d. Stoner, Konflik organisasi adalah mencakup ketidaksepakatan soal alokasi sumber daya yang langka atau peselisihan soal tujuan, status, nilai, persepsi, atau kepribadian.

e. Daniel Webster mendefinisikan konflik sebagai berikut:

1). Persaingan atau pertentangan antara pihak-pihak yang tidak cocok satu sama lain.

${ }^{10}$ Soegarda Poerbakawatja, Pendidikan dalam Alam Indonesia Merdeka(Jakarta: GunungAgung, 1970). Hal 11.

${ }^{11}$ T.HaniHandoko, Manajemen Personaliadan Sumber daya Manusia. Universitas Gajah Mada (Yogyakarta: Universitas Gajah Mada, 1997). Hal 201. 


\section{2). Keadaan atau perilaku yang bertentangan.}

Dari beberapa pengertian konflik di atas, dapat simpulkan konflik adalah suatu pertentangan yang terjadi antara apa yang diharapkan oleh seseorang terhadap dirinya, orang lain, organisasi dengan dengan kenyataan apa yang diharapkan.

Menurut Stevenin terdapat lima langkah meraih kedamaian dalam konflik. Apa pun sumber masalahnya, lima langkah berikut ini bersifat mendasar dalam mengatasi kesulitan sebagai berikut:

a. Pengenalan, Kesenjangan antara keadaan yang ada diidentifikasi dan bagaimana keadaan yang seharusnya. Satu-satunya yang menjadi perangkap adalah kesalahan dalam mendeteksi (tidak mempedulikan masalah atau menganggap ada masalah padahal sebenarnya tidak ada).

b. Diagnosis, Inilah langkah yang terpenting. Metode yang benar dan telah diuji mengenai siapa, apa, mengapa, dimana, dan bagaimana berhasil dengan sempurna. Pusatkan perhatian pada masalah utama dan bukan pada hal yang sepele.

c. Menyepakati suatu solusi, Kumpulkanlah masukan mengenai jalan keluar yang memungkinkan dari orang-orang yang terlibat di dalamnya. Saringlah penyelesaian yang tidak dapat diterapkan atau tidak praktis. Jangan sekali-kali menyelesaikan dengan cara yang tidak terlalu baik. Carilah yang terbaik.

d. Pelaksanaan, Ingatlah bahwa akan selalu ada keuntungan dan kerugian. Hati-hati, jangan biarkan pertimbangan ini terlalu mempengaruhi pilihan dan arah kelompok.

e. Evaluasi Penyelesaian itu sendiri dapat melahirkan serangkaian masalah baru. Jika penyelesaiannya tampak tidak berhasil, kembalilah ke langkah-langkah sebelumnya dan cobalah lagi.

Stevenin juga memaparkan bahwa ketika mengalami konflik, ada hal-hal yang tidak boleh dilakukan di tengah-tengah konflik, yaitu: 1). Jangan hanyut dalam perebutan kekuasaan dengan orang lain. Ada pepatah dalam masyarakat yang tidak dapat dipungkiri, bunyinya: bila wewenang bertambah maka kekuasaan pun berkurang, demikian pula sebaiknya. 2). Jangan terlalu terpisah dari konflik. Dinamika dan hasil konflik dapat ditangani secara paling baik dari dalam, tanpa melibatkan pihak ketiga. 3). Jangan biarkan visi dibangun oleh konflik yang ada. Jagalah cara pandang dengan berkonsentrasi pada masalah-masalah penting. Masalah yang paling mendesak belum tentu merupakan kesempatan yang terbesar. ${ }^{12}$

\section{MODEL ORGANISASI DINAS PENDIDIKAN KOTA DI DAERAH PASCAKONFLIK KOTA AMBON}

Dinas Pendidikan Kota Ambon merupakan unsur pelaksana otonomi daerah Pemerintah Kota di bidang Pendidikan, dipimpin oleh seorang Kepala Dinas yang berkedudukan di bawah dan bertanggung jawab kepada Walikota melalui Sekretaris Kota. Dinas Pendidikan Kota, mempunyai tugas membantu Walikota melaksanakan urusan pemerintahan daerah di bidang Pendidikan dalam rangka pelaksanaan tugas desentralisasi, tugas pembantuan dan tugas-tugas lain yang diberikan oleh Walikota.

Untuk melaksanakan tugasnya Dinas Pendidikan Kota mempunyai fungsi: ${ }^{13}$

1. Perumusan kebijakan dan pelaksanaan teknis di bidang Pendidikan;

2. Menyelenggarakan urusan pemerintahan dan pelaksanaan pelayanan umum di bidang

Pendidikan berdasarkan Peraturan Perundang- undangan;

3. Pembinaan dan pelaksanaan teknis di bidang Pendidikan;

4. Pembinaan Unit Pelaksana Teknis Dinas;

5. Pelaksanaan Urusan Kesekretariatan Dinas; dan

\footnotetext{
${ }^{12}$ Stevenin, 2009. "Manejemen Konflik: Definisi, ciri, Sumber, dampak dan strategi mengatasi konflik",dalamhttp://jurnal-sdm-blogspot.com/search/label/Manajemenkonflik. Di akses 15 Oktober 2014

${ }^{13}$ Peraturan Daerah Kota Ambon, 2008. http://www.jdih.setjen.kemendagri.go.id/files /KOTA_AMBON_9_2008.pdf.Diakses 15 Oktober 2014
} 
6. Pelaksanaan tugas lain sesuai kebijakan yang ditetapkan Walikota di bidang Pendidikan Adapun susunan organisasi dinas pendidikan kota Ambon, sebagai berikut:

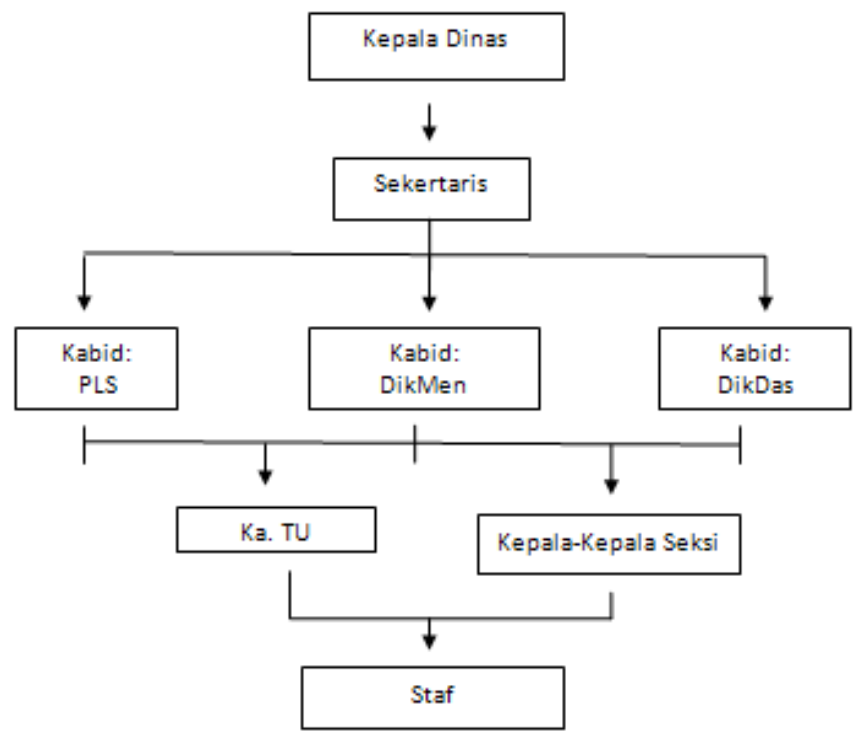

Pascakonflik telah mengakibatkan terjadinya pergeseran arah paradigma pendidikan, dari paradigma lama ke paradigma baru, Sejak awal, pemerintah (pusat dan daerah) haruslah suportif atas gagasan dari para pemerhati pendidikan, yang peduli dengan anak bangsa. Mereka harus mempercayai kepala sekolah dan dewan sekolah untuk menentukan cara mencapai sasaran pendidikan di masing-masing sekolah. Penting artinya memiliki kesepakatan tertulis yang memuat secara rinci peran dan tanggung jawab dewan pendidikan daerah, dinas pendidikan daerah, kepala sekolah, dan dewan sekolah. Perlu diadakan pelatihan dalam bidang-bidang seperti dinamika kelompok, pemecahan masalah dan pengambilan keputusan, penanganan konflik, teknik presentasi, manajemen stress, serta komunikasi antarpribadi dalam kelompok. Pelatihan ini ditujukan bagi semua pihak yang terlibat di sekolah dan anggota masyarakat. Untuk memenuhi tantangan pekerjaan, kepala sekolah kemungkinan besar memerlukan tambahan pelatihan kepemimpinan.

Sejalan dengan kebijakan Walikota Ambon dalam masa kepemimpinannya 5 tahun kedepan bersama dengan wakil walikota terpilih semenjak pascakonflik salah satu yang menjadi perhatiannya secara serius adalah masalah Sumber Daya Manusia baik dalam aparatur pemerintahan maupun tenaga pendidik dan kependidikan yang mampu menghasilkan generasi yang cerdas, kreaktif, inovatif dan mempunyai motivasi yang tinggi sebagai generasi penerus kepemimpinan bangsa ini, khususnya generasi yang ada di Kota Ambon. Dan hal ini apabila tidak dimulai dari sekarang kita akan ketinggalan dengan daerah-daerah lain di Indonesia, sebab kenyataan yang terjadi sebelum dan sesudah konflik ditahun 1999-2000an adanya perubahanperubahan kondisi ekonomi menyebabkan banyak organisasi dari bermacam-macam ukuran melakukan langkah restrukturisasi. Hal ini mendorong terjadinya perubahan paradigma organisasi dari tradisional menjadi modern. Kondisi ini harus benar-benar disadari dan dipersiapkan secara proporsional. Persiapan ini terutama pada faktor-faktor sumber daya manusia yang bermutu dengan kualifikasi yang sesuai.

Oleh karena itu, peningkatan kinerja sumber daya manusia (SDM) merupakan hal yang sangat penting di dalam usaha memperbaiki pelayanan kepada masyarakat, sehingga perlu diupayakan secara terus menerus dan berkesinambungan dalam menghadapi tuntutan masyarakat. Untuk menentukan hal ini perlu dicari faktor-faktor yang mempengaruhi kinerja tersebut. 
Keberhasilan pengelolaan sekolah dapat ditandai dengan pengambilan keputusan bersama. Misalnya, adanya pembagian tanggung jawab antara para pemegang kebijakan, kepala sekolah dapat memberi perhatian pada hal yang berkaitan dengan peningkatan sekolah. Faktor lain yang harus terlibat dari pembagian tanggung jawab dalam pengambilan keputusan adalah memprofesionalkan staf. Untuk pengelolaan sekolah yang baik ada beberapa hal yang harus diperhatikan, antara lain:

1. Komunikasi terbuka.

Adanya komunikasi yang terbuka, para pemegang kebijakan dalam mengambil keputusan akan merasa lebih positif mengenai sekolah. Jika hal itu terbentuk akan menciptakan pondasi yang kuat untuk pengembangan sekolah melalui peran serta masyarakat sekolah.

2. Keputusan diambil bersama.

Keputusan ditetapkan beberapa orang pada hal kebijakan yang diputuskan menyangkut semua elemen. Jika hal itu terjadi lama-kelamaan membawa dampak negatif. Karena pasti ada pihak merasa tidak terpakai sehingga terjadi pertentangan individu. Oleh sebab itu, pengambilan keputusan harus dilakukan secara bersama.

3. Kebutuhan guru diperhatikan.

Guru mempunyai kebebasan untuk bertukar pikiran, termasuk pandangan yang bertentangan dengan kepala sekolah. Kepala sekolah harus melibatkan para guru sehingga mereka merasa dianggap mitra dalam pengembangan sekolah. Sehingga timbul rasa turut memiliki dan meningkatkan peran. Apalagi dalam proses kerja terjadi komunikasi yang terbuka dan memperlakukan guru secara professional. Selain kesejahteraannya guru juga perlu meningkatkan kualifikasi pendidikan ke jenjang yang lebih tinggi. Pemerintah harus bisa menjadi motivator dan fasilitator untuk mendorong para guru melanjutkan ke tingkat yang lebih tinggi.

4. Kebutuhan anak diperhatikan

Kemauan kepala sekolah untuk mendengarkan para anak dapat memberikan dorongan kepada mereka. Langkah yang bisa dilakukan melalui rapat "OSIS" sehingga anak dapat mengutarakan pendapatnya dan mengusulkan saran. Sekolah yang memperhatikan kebutuhan anak akan lebih diterima baik anak, orang tua, juga masyarakat. Kebutuhan bisa dalam bentuk peningkatan pembelajaran, memberikan belajar tambahan menghadap UNAS. Selain itu penambahan kegiatan ektrakurikuler yang positif. Pihak sekolah juga perlu memfasilitasi program latihan keterampilan yang cocok untuk mempersiapkan siswa ke dunia kerja mandiri. Hal lain yang perlu dilakukan membuat sekolah menjadi tempat yang menyenangkan bagi para anak sehingga para anak merasa betah berada di sekolah.

5. Adanya keterpaduan antara sekolah dan masyarakat

Sekolah merupakan tempat anak belajar, maka sekolah mempunyai peran penting dalam masyarakat, jadi seorang kepala sekolah harus melibatkan tokoh masyarakat. Bisa dilakukan dengan cara mengundang tokoh masyarakat pada rapat sekolah saat membicarakan masalah yang berkaitan dengan masyarakat.

6. Guru sebagai model

Pada zaman modern masih ada guru mengajar dengan paradigma lama, siswa dianggap botol kosong yang harus diisi, hal itu sudah ketinggalan zaman. Zaman modern ini seorang guru harus berpikir modern tidak lagi menganggap anaknya botol. Dalam proses belajar mengajar sekarang, guru harus bisa menciptakan suatu suasana belajar yang menarik. Guru juga dituntut untuk bisa menjadi model dalam pembelajaran. Kalau guru tidak bisa menjadi model dalam pembelajaran, hal itu merupakan salah satu faktor penyebab anak kurang perhatian terhadap materi yang disampaikan guru. Hal ini sejalan dengan pendapat Neulis Rahmawati Barlian (2004) menyatakan dalam menyajikan materi, guru belum mampu menjadi model dalam pembelajaran itu. Oleh sebab itu yang diharapkan dalam menyampaikan materi guru harus bisa menjadi model yang materinya berdasarkan pengalamannya, bukan hanya berdasarkan teori dalam buku. Pembelajaran yang berpusat pada anak pada prinsipnya adalah 
pembelajaran yang bersifat keterampilan sehingga dapat langsung diaplikasikan dalam kehidupan sehari-hari anak hal ini sesuai dengan konsep dasar life skill (kecakapan hidup) yang menyangkut kecakapan mengenal diri, kecakapan berpikir rasional, kecakapan sosial, kecakapan akademik, dan kecakapan kerja. Sehingga pada saat pembelajaran guru tidak hanya menyuruh siswa membaca atau menulis, sedangkan gurunya sendiri tidak pernah melakukannya. Hal yang dikemukakan di atas hanya sebuah harapan yang diharapkan bisa terwujud.

\section{PENUTUP}

Sekolah memiliki tanggungjawab yang besar menyiapkan anaksebagaitenaga terampil dan terdidik yang memiliki daya saing. Terkait dengan hal tersebut, wajar apabila manajemen organisasi sekolah yang baik akan menciptakan proses pendidikan yang bermutu. Proses yang bermutu akan menghasilkan out put yang berkualitas. Saat ini tuntutan masyarakat terhadap peningkatan mutu pendidikan semakin tak terbendung. Pasalnya, keunggulan sebuah bangsa tidak lagi dipandang dari kekayaan Sumber Daya Alam (SDA), tetapi dilihat dari keunggulan Sumber Daya Manusia (SDM) yang dimiliki, yakni tenaga terampil yang mampu mengantisipasi dan menyesuaikan diri terhadap dinamika kehidupan global atau internasional. Ini merupakan salah satu dampak globlalisasi.

Dinas pendidikan kota Ambon merilis kembali model organisasi yang mampu mengefektifkan kembali proses pembelajaran di lembaga-lembaga pendidikan agar tujuan yang ingin dicapai dapat diwujudkan. Adapun model organisasi dinas pendidikan kota Ambon menerapkan model birokrasi yakni Dinas Pendidikan Kota Ambon merupakan unsur pelaksana otonomi daerah Pemerintah Kota di bidang Pendidikan, dipimpin oleh seorang Kepala Dinas yang berkedudukan di bawah dan bertanggung jawab kepada Walikota melalui Sekretaris Kota. Dinas Pendidikan Kota, mempunyai tugas membantu Walikota melaksanakan urusan pemerintahan daerah di bidang pendidikan dalam rangka pelaksanaan tugas desentralisasi, tugas pembantuan dan tugas-tugas lain yang diberikan oleh Walikota.

Dengandemikian seorang pemimpin dalam suatu organisasihendaknya dapat mengambil keputusan yang tepat dan menerapkan gaya kepemimpinan sesuai dengan situasi dengan berbagai pertimbangan yang telah diperhitungkan secara matang.Kepemimpinan bangsa yang sadar akan makna pendidikan sebagai investasi utama bangsa dan mampu menciptakan revenue sehingga mampu mendukung secara efektif penyelenggaraan sistem persekolahan yang bermutu dan adil merata. Ini berlaku bagi kepemimpinan tingkat nasional, tetapi juga kepemimpinan daerah sejak otonomi memberi kekuasaan besar pada daerah.***

\section{REFERENSI}

Depdiknas. 2005.Rencana Strategis Departemen Pendidikan Nasional Tahun 2005 - 2009. Jakarta: Departemen Pendidikan Nasional.

Dewantara, Ki Hajar. 1962. Bagian Pertama Pendidikan, Yogyakarta: Majelis Luhur Persatuan Taman Siswa.

Marimba, Ahmad D. 1962. Pengantar Filsafat Pendidikan Islam, Bandung: Al- Ma'arif.

Peraturan Daerah Kota Ambon, 2008. http://mmw.jdih.setjen.kemendagri.go.id /files /KOTA_AMBON_9_2008.pdf. Diakses 15 Oktober 2014

Poerbakawatja, Soegarda. 1970. Pendidikan dalam Alam Indonesia Merdeka, Jakarta: GunungAgung.

Sonhadji, 2013. Bahan-bahan Perkuliahan Teori dan Model dalam Bidang Studi. Malang: Universitas Negeri Malang Program Pascasarjana. 
Stevenin, 2009. Manejemen Konflik: Definisi, ciri, Sumber, dampak dan strategi mengatasi konflik. (bttp:/ / jurnal-sdm-blogspot.com/ search/label/Manajemenkonflik).Di akses 15 Oktober 2014

Suprijono, A. 2009. CooperativeLearning. Surabaya: Pustaka Pelajar.

T. HaniHandoko, 1997. ManajemenPersonaliadanSumberdayaManusia. Universitas Gajah Mada, Yogyakarta: Universitas Gajah Mada.

Tafsir, Ahmad. 1994. Ilmu Pendidikan dalam Perspektifj'slam, Bandung: Remaja Rosdakarya. cet. IV.

Trianto, 2009. Model-model Pembelajaran Inivatif Berorientasi Konstruktivistik. Jakarta: Kencana Prenada Media Group.

Usman Husaini, 2013. Manajemen Teori, Praktik, dan Riset Pendidikan. Edisi 4. Yogyakarta: Bumi Aksara.

Rahman, A. 2009. "Pengembangan Mobil Pintar untuk Daerah Tertinggal, Pasca Konflik, dan Rawan Bencana”.http://edukasi.kompas.com / read/2009/08/06/14542844/ Arief. Anak di Daerah Konflik Butuh Pendidikan Informal. Diakses 15 Oktober 2014. 